\title{
МОЛИТВЕНИ ЗАПИС НА СВИТКУ КТИТОРСКЕ ФРЕСКЕ ДЕСПОТА СТЕФАНА ЛАЗАРЕВИЋА*
}

\begin{abstract}
Запис на ктиторској фресци деспота Стефана Лазаревића у манастиру Ресави (Манасији), иако веома оштећен, важно је сведочанство о Деспотовом књижевном раду - сматрам да га је саставио сам Деспот - а представља и неку врсту надокнаде за изгубљену манастирску повељу, коју је Деспот несумњиво морао издати за своју главну задужбину.

Кључне речи: деспот Стефан, Константин Философ, манастир Ресава (Манасија), ктиторска фреска Деспотова, ктиторски свитак.
\end{abstract}

Деспотов биограф Константин Философ описује у Житију како је деспот Стефан Лазаревић тражио и пронашао место где ће сазидати своју задужбину и гробну цркву - манастир Ресаву (Манасију): „Пошто нађе најприкладније и најбоље где би дом (тај) требало да буде, помоли се, прихвати се посла и постави темељ у име Свете Тројице, сведржавног божанства. И свуда је, са великом журбом (налазећи) веште и најбоље градитеље и искусне живописце, где год да (их) је било, украсио (тај манастир) златним (украсима) и цветним шарама. Слао је (по мајсторе) свуда, чак и на острва. Сагради се (ова обитељ) уз многе и огромне трошкове и украси се (тај) дом и град око њега... Сакупи са свих страна веома умне и изузетне монахе и насели их ту. Приложи и даде (манастиру) села $и$ винограде по читавој својој земљи (и) потписом (потврди). Овде из дана

\footnotetext{
"Рад је објављен у зборнику: Средњи век у српској науци, историји, књижевности и уметности, IV, Деспотовац: Народна библиотека „Ресавска школа”, 2013, 17-27.
} 
у дан полагаше драгоцености. Ту начини себи и гробницу, где ускоро би положен". ${ }^{1}$

Овај опис Деспотовог градитељског подухвата садржи и за овај рад важну реченицу, наиме, да је даривао манастир многим добрима - селима, виноградима, односно да је манастир Ресава морала имати велики метох, у коме су морали бити и пашњаци, шуме, уљаници (пчелињаци), рибњаци и још много других ствари неопходних за живот манастира. Сви ти дарови морали су бити записани и потврђени Деспотовим печатом и потписом; другим речима, манастир је несумњиво имао и даровницу (повељу) о свом оснивању, у којој је било побројано све што је манастир поседовао. Нажалост, та се Деспотова повеља манастиру Ресави (Манасији) није сачувала. Она је могла бити написана на свитку од пергамента или на манастирском зиду, а можда је постојала и у једном и другом виду.

Да нам се сачувала Деспотова повеља, данас бисмо знали и која су села у ближој или даљој манастирској околини била њему дарована, као што знамо која је села његов отац, кнез Лазар, даровао Раваници. Највећа група свих прилога дарованих манастиру Раваници налазила се „у поречју Велике и Јужне Мораве, као и њеног изворног дела...”2 Многа од тих села и данас постоје, на пример, село Сење (у повељи: Сена Доњ $a^{3}$ и Сена Горња), село Буљани (јужно од Сења), село Кованица (у повељи: Окованица Доњаја, Окованииа Горњаја), село Жидиље (Џидиље), уз које се спомиње и црква Светог Пантелејмона ${ }^{4}$ итд. Не треба сумњати у то да су се села дарована манастиру Ресави (Манасији), или бар нека од њих, морала налазити у области Ресава (Горња и Доња), а и по другим областима Деспотовине. Из шездесетих година XIX века постоје писани подаци о томе да су парохију (нурију) манастира Манасије сачињавала села: Војник, Буковаи, Милива, Витанаи (Витанце), Бељајка, Кованица, Језеро, Поповљак (Поповњак), Ресавииа. Укупно је било петсто осамдесет пет кућа. ${ }^{5}$ Сасвим је вероватно да су бар нека од ових села припадала и

\footnotetext{
${ }^{1}$ К. Философ, Живот Стефана Лазаревића, деспота српскога, превод и напомене Г. Јовановић, Издавачки фонд Српске православне цркве Архиепископије београдско-карловачке, Београд, 2009, стр. 62.

${ }^{2}$ А. Младеновић, Повеље кнеза Лазара, Чигоја штампа, Београд, 2003, стр. 67.

${ }^{3}$ У Браничевском дефтеру из 1467. године забележено је село Дольа Сена, М. Стојаковић, Браничевски тефтер, Историјски институт, Београд, 1987, стр. 175.

${ }^{4}$ А. Младеновић, нав. дело, стр. 68-69. Данас црква више не постоји, али се несумњиво у народном памћењу сачувало њено постојање, јер је сеоска заветина и данас, иако је село скоро опустело, Свети Пантелејмон.

${ }^{5}$ St. Stanojević, Laz. Mirković, Dj. Bošković, Le monastère de Manasija, Musee National de Beograde, Monuments serbes V, Beograde, 1928, str. 8.
} 
некадашњем манастирском властелинству. ${ }^{6}$ Досад једини, најпотпунији и пажње вредан покушај да се одреде границе метоха манастира Ресаве дала је Гордана Томовић. Упоређујући га с метохом манастира Раванице, сматра да се простирао „између десне обале Мораве и планине Кучај”7 и бројао је шездесет два села. Даље, Г. Томовић с разлогом закључује да се деспот Стефан, подижући манастир Свету Тројицу на Ресави, „руководио жељом да његова задужбина буде што је ближе могуће очевој, па су се и њихове метохије додиривале, уз поштовање постојећих међа. Северне границе раваничког метоха око самога манастира Раванице биле су истовремено и јужне границе црквених поседа груписаних око Деспотове цркве". ${ }^{8}$ На посредан начин може се утврдити да је на обали Дунава код Острова и Сребрног језера, западно од Великог Градишта, постојао један ресавски метох. Део властелинства који је припадао манастиру Ресави „био је ограничен према југу и ка северозападу, према Великој Морави, већ постојећим поседима манастира Раванице".

У Браничевском дефтеру постоји занимљив и важан податак. ${ }^{10}$ Наиме, свештеник Никон поседује тимар, ${ }^{11}$ у који спадају и села Горња Сена и Долња Црвена Стена. ${ }^{12}$ Овом свештенику придодат је и манастир Светодухна (Ресава - Манасија). Истиче се да су „свештеници опроштени и ослобођени од давања". ${ }^{13}$ Б. Тодић реконструише назив првог села као Горња $C(m)$ ена. ${ }^{14} \mathrm{y}$ дефтеру се само наводи да је то село данас непознато и даје се лик Горња Сена. ${ }^{15}$ Међутим, постоји село Горња Црвена Стена, такође у Ресави и такође данас непознато, али је његов тимарник неки Дивана Илијас, посадник тврђаве Ресава. ${ }^{16}$ Непознато је и село Долњ $а$ Црвена Стена, тимар свештеника Никона. Сва три села су, дакле, у Ресави. И вероватно сасвим близу једно другоме. На основу чега то претпостављам? У Горњој Ресави и данас постоји село Стењевац. Оно се дели на горњи и доюи крај и сасвим је могуће да је та подела у народном

\footnotetext{
${ }^{6} \mathrm{O}$ топономастици Раваничког властелинства са посебним освртом на поседе у манастирској околини постоји рад Ђ. Симоновића објављен у Гласнику Етнографског музеја САНУ XXIX, Београд, 1980. За властелинство манастира Ресава таквих података нема.

${ }^{7}$ Г. Томовић, Ресавска метохија и нахија Ресава, Деспот Стефан и његова Манасија, Дани српскога духовног преображења XV, Деспотовац, 2008, стр. 12.

${ }^{8}$ Исто, стр. 12.

${ }^{9}$ Исто, стр. 16.

${ }^{10}$ На њега је скренуо пажњу Б. Тодић у својој монографији Манастир Ресава, Београд, 1995, стр. 21.

${ }^{11}$ Тимар - „турско војнофеудално добро које је додељивано спахији”, М. Стојаковић, нав. дело, стр. 293.

${ }^{12}$ Исто, стр. 250-251.

${ }^{13}$ Исто, стр. 251.

${ }^{14}$ Б. Тодић, нав. дело, стр. 21.

${ }^{15}$ М. Стојаковић, нав. дело, стр. 250.

${ }^{16}$ Исто, стр. 238.
} 
сећању остала од некадашњих села Горьа и Доња Црвена Стена, која су се спојила у једно село, данашњи Стељьеваи. ${ }^{17}$ Б. Тодић износи занимљиву претпоставку, која није без основа, да су та два села „једини остаци некадашњег властелинства које је деспот Стефан даровао манастиру, а да је Никон, заправо, игуман манастира". ${ }^{18}$

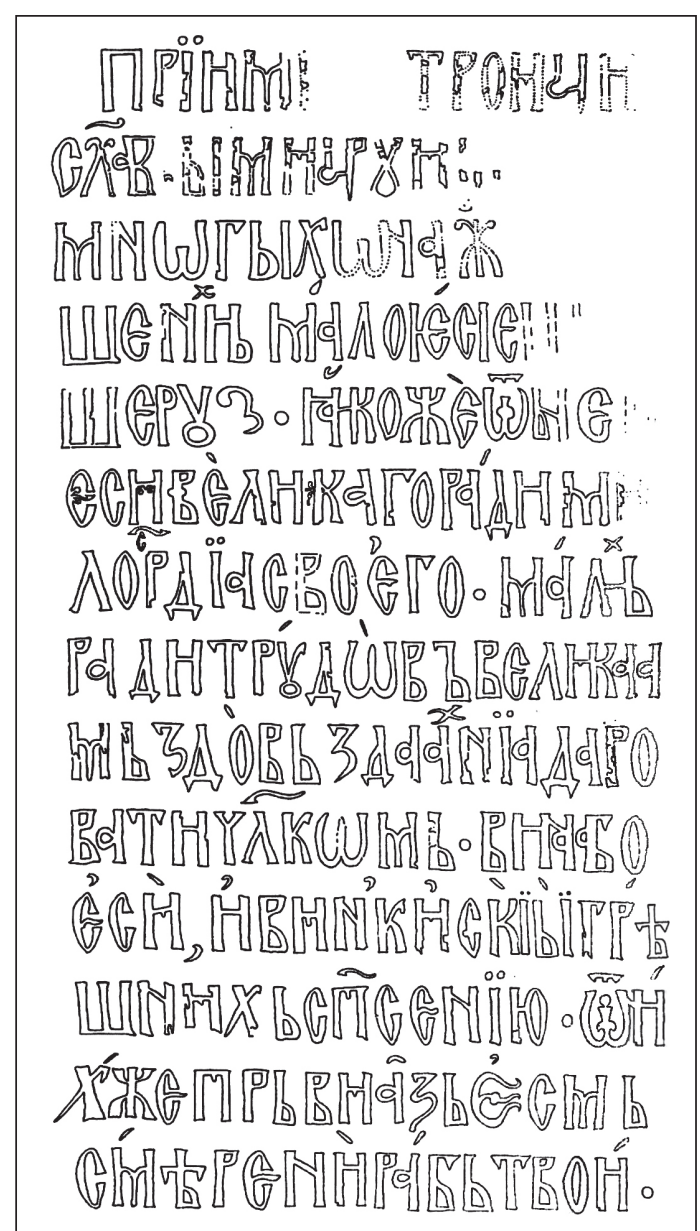

Текст свитка у рукама ктитора деспота Стефана Лазаревића

${ }^{17}$ Г. Јовановић, Насељена места у Ресави у турско доба, Средњи век у српској науци, историји, књижевности и уметности, Дани српскога духовног преображења XVII, Деспотовац, 2010, стр. 103-104.

${ }^{18}$ Б. Тодић, нав. дело, стр. 21. О овоме такође в. Б. Кнежевић, Манастири и иркве у Ресави, Ресава (Горња и Доња) у историји, науци, књижевности и уметности, Дани српскога духовног преображења XI, Деспотовац, 2004, стр. 71-94. О топонимији у Ресави у XV веку в. М. Грковић, Топоними у Ресави у петнаестом веку, Ресава (Горња и Доња) у историји, науци, књижевности и уметности, Дани српскога духовног преображења XI, Деспотовац, 2004, стр. 95-100. 
Архимандрит манастира Манасије Јевгеније Симеоновић ${ }^{19}$ оставља нам сведочанство о томе да је игуман манастира око 1804. године био Јоаникије, родом из Лесковца. Дошавши у Манасију, затекао је саму пустош. Саградио је колибицу за себе, а замолио је Буковчане, Војничане и Витанчане да му помогну да очисти и среди цркву, после чега је народ масовно почео долазити на богослужења. ${ }^{20}$

Сви ови помени - било села, било њихових становника, а да су у вези са манастиром Манасијом - на неки посредан начин говоре о поседима које је манастир имао у време Деспотовине; било у писаном облику, било у народном памћењу, сачувало се понешто од онога што је Деспотова дворска канцеларија до у танчина забележила, а деспот Стефан потврдио својим печатом и потписом.

Ових неколико података који се тичу историјата манастира Манасије представљају неку врсту неопходног увода у основну тему овога рада. Наиме, шта садржи запис на свитку који се налази на ктиторској фресци деспота Стефана. И стварно - питање није неумесно и треба га започети речима: „Шта садржи запис на свитку...?”.

Овај запис спада у књижевну заоставштину манастира Ресаве (Манасије), као и српскословенски натписи на његовим фрескама. И тако се према њима и треба односити, јер су они једино, несумњиво и сачувано сведочанство о градитељству Ресаве, о њеном живопису, о великом књижевном прегнућу које је настало међу њеним зидинама, о мајсторима који су осликавали цркву, чија је дужина $22 \mathrm{~m}$, без припрате, ширина $14,28 \mathrm{~m}$, а висина око $25 \mathrm{~m} .{ }^{21}$ Они су остављали драгоцене натписе на фрескама у најбољој традицији српскословенског језика. ${ }^{22}$ То су пригодни цитати из Старог и Новог завета. Неки од тих мајстора, а логично је претпоставити да је то био главни мајстор, записао је и текст на свитку Деспотове ктиторске фреске.

Погледајмо најпре опис ктиторске фреске из пера наших истакнутих историчара уметности. Она се налази на западном зиду, десно од главних, средишњих врата. Деспот је у раскошној одећи, са владарским инсигнијама у рукама: Христос из сегмента неба ставља му круну на гла-

\footnotetext{
${ }^{19}$ Архимандрит Евгеније Симеоновић написао је око 1860. године чланак под насловом Описъ манастира Манасіе и штампао га у часопису Србску́й лътописъ за годину 1863. часть друга, година XXXVII, кньига 108, У Будиму 1864, стр. 51-59. На крају свога рада он се потписао иницијалима С. А., а не А. С., како то наводи Ст. Станојевић на стр. 5, нап. 11. Вероватно: Симеоновић архимандрит.

${ }^{20}$ Исто, стр. 58-59; такође в. Манасија, историја-живопис, ред. С. Томић, Р. Николић, Београд, 1064, стр. 33.

${ }^{21}$ Б. Тодић, нав. дело, стр. 38.

${ }^{22} \mathrm{M}$. Кашанин ће за ресавске натписе на фрескама рећи да су то „неговани српски натписи, који теку и спонтано и без језичких грешака”; в. М. Кашанин, Ресава деспота Стефана, Зограф, часопис за средњовековну уметност, 3, Београд, 1969, стр. 8.
} 
ву, а два анђела му уручују мач и копље; у левој руци држи исписани свитак и модел цркве, коју предаје Светој Тројици. Она је приказана у лику три анђела, који у левој руци држе дуге палице, а десном руком благосиљају деспота Стефана са два прста. Модел манастира Ресаве као да је наслоњен једним својим делом на ишаран мраморни камен. У позадини Свете Тројице види се нека грађевина. ${ }^{23}$ Важан је и податак о томе да се у манастиру Ресави први пут јавља представа Свете Тројице у ктиторској композицији. У Сопоћанима, који су такође посвећени Светој Тројици, краљ Урош не предаје модел своје задужбине Светој Тројици. ${ }^{24}$

Вероватно и пре XI века у Византији и Србији био је познат обичај да се уз даровнице или оснивачке повеље сликају портрети ктитора. У иконографији познат је и други начин сликања владара ктитора: ктитор је представљен са моделом храма, који држи у једној руци - или без модела храма - а у другој држи отворени свитак. На њему је исписан текст молитве упућене Христу, у којој ктитор моли Господа да прими његов скромни дар и да му на одговарајући начин укаже своју милост и помоћ. У српском зидном сликарству XIV и XV века постоје таква иконографска решења. На једном од њих је краљ Вукашин са својим сином краљем Марком; они су тако осликани два пута: једном око 1371. у манастиру Светих арханђела у Прилепу, а други пут 1376. године у Марковом манастиру. Оба се налазе поред улаза у цркву, као и ктиторски портрет деспота Стефана Лазаревића. ${ }^{25}$

Када је реч о тексту исписаном на свитку који држи у руци деспот Стефан, он се може упоредити са текстом свитака које држе у рукама краљеви Вукашин и Марко у Марковом манастиру. Они су специфични по томе што представљају веома сажет текст повеље, са познатим дипломатичким узусима: интитулацијом, дескрипцијом и санкцијом. На Деспотовом свитку таквог нечег нема, ${ }^{26}$ што је потпуно тачно. То је типично „мољеније” (молба, молитва), којим се изражава „тражење, зазивање, мољење, надање, вапај. Мољеније је постојало и као посебна књижевна врста". ${ }^{27}$ Запис на Деспотовом свитку, који је веома оштећен и у доброј мери нечитљив, представља обраћање Деспотово самоме Исусу Христу,

${ }^{23}$ St. Stanojević, Laz. Mirković, Dj. Bošković, nav. delo, str. 50; Мaнасијa, историја - живопис, стр. 55; Б. Тодић, нав. дело, стр. 64, 103.

${ }^{24}$ Манасија, историја - живопис, стр. 55.

${ }^{25}$ В. Ђурић, Портрети византијских и српских владара с повељама, Есфигменска повеља деспота Ђурђа, Београд, 1988, стр. 48.

${ }^{26}$ В. Ђурић каже: „Формула молитве која је исписана на развијеном свитку у руци деспота Стефана има такву садржину да би се могло закључити да је намера ктитора била да, кроз кратак текст, сажме основну идеју из аренге или санкције манастирске оснивачке повеље, не исписујући, као раније, читаву повељу in extenso", исто, стр. 48.

${ }^{27}$ Ђ. Трифуновић, Азбучник српских средњовековних књижевних појмова, Београд, 1990, стр. 172-173. 
једноме од лица Свете Тројице, са молбом да прими његов мали принос, односно цркву и да, пошто је милосрдан, па и за мале заслуге награђује људе великим наградама и хоће да спасе грешнике, спаси и њега - Деспота, који је први грешник међу грешницима.

У време када је сликар конзерватор Б. Живковић радио на рестаурацији ресавског живописа (почевши од 1956. године) запис на свитку био је у већој мери читљив, мада и тада са знатним оштећењима. ${ }^{28}$ Он је покушао да га прочита, односно да разреши све графеме, од којих су многе лигатурног типа, да разбије углавном континуирано писање (scriptura continua) на речи које су смислене и да реконструише нека слова чије је делове могао назрети. Нешто од Живковићеве реконструкције текста и његовог читања може се прихватити, а нешто не. Уосталом, он није био ни филолог, ни историчар, него сликар конзерватор, који је прецртавао слова онако како их је он видео. Његов циљ је, очигледно, био да прецрта (прекопира) слова на запису, а не да разрешава смисао записа. ${ }^{29}$

Много раније, 1928. године, Л. Мирковић у познатој монографији Le monastère de Manasija, ${ }^{30}$ пишући о ресавском живопису, није пропустио да прокоментарише и запис на Деспотовом свитку. Он је дао своје читање, које наводим:

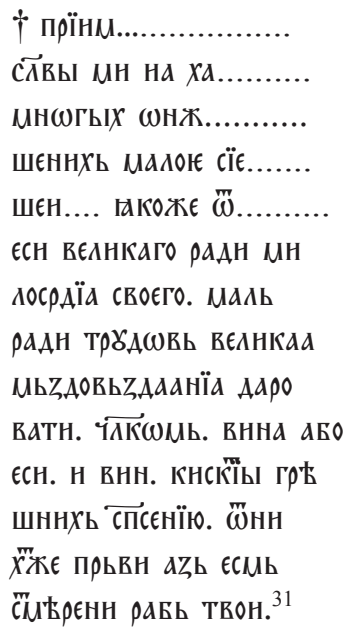

\footnotetext{
${ }^{28}$ Б. Живковић, Манасија. Цртежси фресака, 2, Споменици српског сликарства средњег века, Републички завод за заштиту споменика културе, Београд, 1983, стр. 4.

${ }^{29}$ Његов прекопирани текст прилажем уз свој рад.

${ }^{30}$ B. нап. 23.

${ }^{31}$ St. Stanojević, Laz. Mirković, Dj. Bošković, nav. delo, str. 50.
} 
Гордана Томовић ${ }^{32}$ и ја, трудећи се да анализирамо сваки сегмент овога записа, да узмемо у обзир све могућности читања, дајемо своју варијанту, за коју мислимо да се може научно бранити:

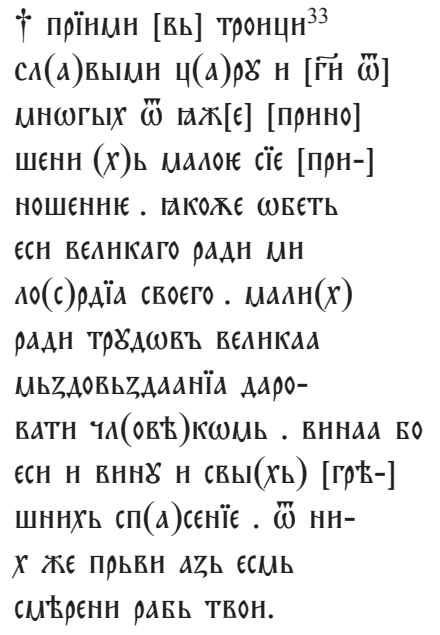

\section{Превод:}

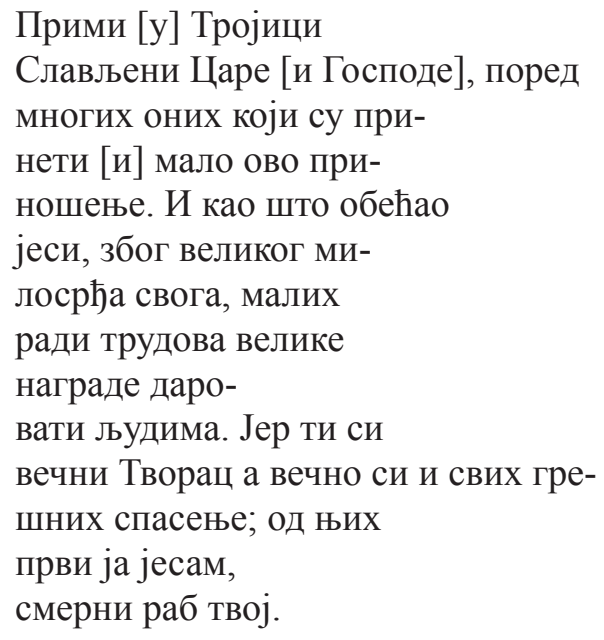

Коментар би се односио на нека моја размишљања у вези са овим текстом на свитку и са неким деловима из Деспотове даровнице лаври Светог Атанасија на Светој Гори. Текст на свитку није даровница (повеља), него

\footnotetext{
${ }^{32}$ Велику захвалност дугујем др Гордани Томовић на заиста драгоценој помоћи и многим одличним сугестијама кад је реч о целовитом тумачењу овога записа.

33 Запис на свитку има четрнаест редова.
} 
је то молитва (мољење) Деспотово упућено Светој Тројици, о чему је већ било речи. Даровнице имају своју устаљену дипломатичку конструкцију, зна се како почињу, како се завршавају, шта садржи њихов средишњи део итд., што је такође раније поменуто. Дакле, овај запис то није. Међутим, изгледа да су неке реченице из Деспотове повеље лаври Светог Атанасија од 20. јануара 1427. године ${ }^{34}$ ипак утицале и на овај запис, односно да су у неком смислу препричане и укомпоноване у њега. Наводим део повеље:

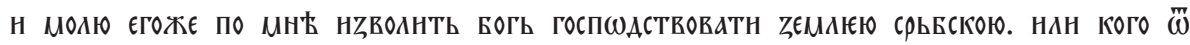

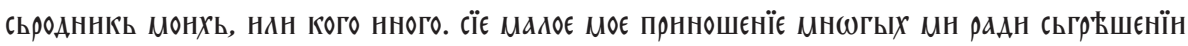
прндожєнноє намн, нєразорнио н непотворєно вытн, нь пачє потврьжАєнно. ${ }^{35}$ У преводУ овај део гласи: И молим онога кога Бог одреди после мене да господари Српском земьом, било некога од мојих рођака или неког другог, да овај мој мали дар, који сам приложси због многих мојих грехова, остане (не само) неуништен и неизмењен већ, штавише, и потврђен. ${ }^{36}$ Болдирани део реченице директно асоцира на садржај неких реченица из записа, на пример, под 4, 5, 11, 12, 13, 14, у којима се говори о томе да је то мали дар (принос), али и мали дарови, по великом Божијем милосрђу, доприносе људском спасењу, па и спасењу самога Деспота. ${ }^{37}$

Пишући о књижници манастира Манасије, дала сам и неке напомене које се тичу натписа на ресавским фрескама, а у оквиру тога скренула сам пажњу и на запис на Деспотовом свитку. ${ }^{38}$ Језик натписа на фрескама, као и језик на свитку, јесте српскословенски. М. Кашанин је, хвалећи оригиналност ресавских живописаца, чија уметност наговештава „нову епоху у православном сликарству на Балкану", ${ }^{39}$ похвалио и записе на фрескама. ${ }^{40}$ Фрескописци који су осликавали фреску били су истовремено, према мишљењу неких научника, и писари који су исписивали текст

${ }^{34}$ А. Младеновић, Повеље и писма деспота Стефана Лазаревића, Чигоја штампа, Београд, 2007, стр. 259.

${ }^{35}$ Исто, стр. 260.

${ }^{36}$ Исто, стр. 264.

${ }^{37} \Gamma$. Томовић ми је скренула пажњу на неке одлике Деспотовог књижевног стила, као што је алитерација - употреба речи сличног звука, на пример, вина је именица и значи 'узрок, почетак, повод', а вину је прилог и значи 'увек, непрекидно' (лат. semper), и овде су употребљене по звуковној сличности. Она такође сматра да реч која се налази у деветом реду и у тексту гласи „мздовзданија” треба прочитати као две речи: „мзда” 'награда' и „зданије” 'дело' (опет исто сазвучје), јер у речницима није нашла потврду за „мздовзданије”. Творбени модел за овакву сложеницу постоји (на пример, код Ђ. Даничића у Рјечнику из књижевних старина српских, 2, имамо потврде: МьZдовьZААтєАь, МьZАоАатєАь, МьZАоПодатєАь), па је Деспот сам могао сачинити нову реч. У овом случају остала бих при свом преводу.

${ }^{38}$ Г. Јовановић, Къижница манастира Манасије, Средњи век у српској науци, историји, књижевности и уметности III, Дани српскога духовног преображења XIX, Деспотовац, 2012, стр. 82.

${ }^{39}$ М. Кашанин, нав. дело, стр. 8.

${ }^{40}$ B. нап. 8 . 
изнад или поред ње. И о њима ће се изрећи следећи суд: „Нигде у српском средњовековном фреско-сликарству натписи нису изведени с таквом вештином као у Манасији. Рукопис главног мајстора свуда је присутан. Она слова која је он исписао на свитку пророка Софонија и Соломона, када је насликао светитеље како пишу, уочиће се на сваком месту где се сачувао писани текст"; ;1 од нарочитог значаја је тврдња да је баш мајстор - фрескописац био и писар натписа пошто, у техничком смислу, није било могуће да се накнадно допишу речи које би се завршавале баш тачно на месту на коме је сликар насликао перо. О томе да су сликари исписивали и натписе, сведоче и многе језичке грешке које се јављају у исписаним текстовима, као што је то у натписима у манастиру Високи Дечани. ${ }^{42}$

Колико сам успела да проучим натписе на ресавским фрескама (на основу цртежа Б. Живковића), нисам приметила језичке грешке. Оно што би се могло оквалификовати као нетачно, резултат је нетачног читања сликара конзерватора и сасвим се лако, на основу пажљивије анализе, може исправити. Дакле, ресавски сликари нису били само врхунски живописци него и веома писмени и образовани људи. Стога ми је стварно тешко да објасним неке језичке нејасноће у Деспотовом свитку, нарочито у делу десетог реда и у средини једанаестог. Помишљала сам, а та ме мисао не напушта, на то да је у питању тајнопис, који је из неког разлога примењен у ова два реда. Међутим, нисам могла, имајући при руци чланак Ђ. Даничића о тајнопису у старим српским рукописима, ${ }^{43}$ да било шта одгонетнем. Прихватам, за сада, да је читање Г. Томовић најприхватљивије, иако ми је и даље тешко поверовати у то да су се у тако репрезентативном и невеликом тексту могле наћи речи исписане тако да омогућавају различита читања или, просто, признања истраживача да је текст неразумљив и нејасан. На ово се надовезује и моје чврсто убеђење у то да је текст ауторско дело самога Деспота и да спада у његове књижевне радове. ${ }^{44}$ Ко би други, ако не он, саставио ово кратко мољеније, које је сасвим у духу хришћанске скромности и лепо по свом језичком исказу? Многи векови у којима је Деспотова задужбина преживљавала тешке и трагичне дане оставили су трагове не само на фрескама него и на натписима, па и на овоме запису. Томе су, по свој прилици, допринели можда не увек савесни и стручни конзерваторски радови. Не може бити сумње у то да је 1418. године, када су црква Свете Тројице и град били завршени, а црква и осликана, и запис на свитку у оквиру ктиторске фреске

\footnotetext{
${ }^{41}$ Манасија, историја -живопис, стр. 89.

${ }^{42}$ Исто

${ }^{43}$ Ђ. Даничић, Тайна буквииа у старимъ рукописима, Гласникъ Друштва србске словесности XI, у Београду, 1859, стр. 171-180.

${ }^{44}$ Ђ. Трифуновић у својој књизи Деспот Стефан Лазаревић, Книжевни радови, Београд, 1979, не наводи овај запис као Деспотово ауторско дело.
} 
био сасвим јасан, читљив и разумљив. Зар би Деспот дозволио да буде другачије?

И за крај. И натписи на ресавским фрескама и запис на свитку спадају у књижевност Деспотовине. Натписи на фрескама дело су и главног мајстора и мајстора сликара (свакако из исте мајсторске радионице); ваљда се може претпоставити да је запис на свитку дело главног мајстора. И натписи и запис спадају у оно што се зове „ресавско писаније” - то су, кроз читав средњи век, па и касније, веома цењени рукописи „ресавског извода", познати по својој тачности и писмености. А запис на свитку спада, како ја мислим, и у Деспотове књижевне радове. 